\title{
68. BROADBAND DOWNHOLE DIGITAL SEISMOMETER EXPERIMENT AT SITE 794: A TECHNICAL PAPER ${ }^{1}$
}

\author{
Kiyoshi Suyehiro, ${ }^{2}$ Toshihiko Kanazawa,${ }^{3}$ Naoshi Hirata, ${ }^{4}$ Masanao Shinohara,,${ }^{4,6}$ and Hajimu Kinoshita ${ }^{5}$
}

\begin{abstract}
A broadband seismic observation was made for the first time in a competent rock section beneath sediments of an ocean. A digital broadband (DC-30 Hz) seismometer was successfully emplaced in Hole 794D in the Japan Sea during Leg 128 by JOIDES Resolution. The installation did not require any tools not standard in ODP drilling. The seismometer capsule about $3 \mathrm{~m}$ long was clamped within basaltic rock section at $714.5 \mathrm{mbsf}$ at a water depth of $2807 \mathrm{~m}$.

Its three-component data are telemetered via the logging cable to a shipboard real-time recording device or to a seafloor off-line digital data recorder. Real-time recording allows full recovery of six-channel data (two gains per component, 16-bit each) at $80 \mathrm{~Hz} /$ channel sampling rate. A controlled source seismic experiment was conducted during this phase (about $60 \mathrm{hr}$ ) to obtain detailed local crustal structure.

In an attempt to observe deep and teleseismic events, a seafloor recorder package was deployed together with a lead-acid battery power supply by a supporting vessel. This first-design package operated for about 1.5 months to record $60 \mathrm{Mbytes}$ of data in two modes: (1) event detection and (2) time window. It was retrieved about 8 months after the deployment.
\end{abstract}

\section{INTRODUCTION}

In fall 1989, we successfully installed an ocean broadband downhole seismometer (OBDS) in Hole 794D during Leg 128 (Ingle, Suyehiro, von Breymann, et al., 1990). Our specific aim of installation was to better image the laterally heterogeneous crust-mantle structure beneath the Japan Sea, backarc of the northern Japan subduction zone, from a permanent seismic station previously nonexistent in conjunction with existing land stations (Fig. 1).

It has long been considered a major step forward in observational seismology to develop a permanent seismic station that operates on the seafloor. But there seems to be no single path to this goal. System requirements vary among different objectives. There is no consensus on what environment, whether seafloor, or within competent rock, or in between, should give "sufficient" signal-to-noise $(\mathrm{S} / \mathrm{N})$ ratio. Technical difficulties regarding power supply and data retrieval have been pointed out (e.g., COSOD II, 1987). Leveling and stabilizing the sensor is another problem. More importantly, broadband observational data scarcely exist for assessment (Sutton et al., 1965).

To date, there have been a number of seismic observations of frequency band above about $1 \mathrm{~Hz}$ utilizing the drilled holes. Vertical seismic profiling or oblique seismic experiment have been carried out to study detailed upper crustal structure taking advantage of a fixed coordinate, variable depth observation (e.g., Stephen et al., 1980; Stephen et al., 1983). But the presence of mechanical noise from the ship and drill string and limited observation time prohibit global seismology type studies.

The University of Hawaii group (HIG) has made four seismic experiments to seek quiet environment at four sites on Legs 65, 67, 78A, and 88 (Lewis, Robinson et al., 1983; Aubouin, von Huene, et al., 1982; Biju-Duval, Moore, et al., 1984; Duennebier, Stephen, Gettrust, et al., 1987). Navy Ocean Research and Development Activity (NORDA) has conducted three experiments on Legs 78B, 88, and 91 (Hyndman, Salisbury, et al., 1984; Duennebier, Stephen,

\footnotetext{
Tamaki, K., Suyehiro, K., Allan, J., McWilliams, M., et al., 1992. Proc. ODP, Sci. Results, 127/128, Pt. 2: College Station, TX (Ocean Drilling Program).

${ }^{2}$ Ocean Research Institute, University of Tokyo, Tokyo 164, Japan.

${ }^{3}$ Faculty of Science, University of Tokyo, Tokyo 133, Japan.

${ }_{5}^{4}$ Department of Earth Sciences, Chiba University, Chiba 260, Japan.

${ }_{6}^{5}$ Earthquake Research Institute, University of Tokyo, Tokyo 113, Japan.

${ }^{6}$ Present address: Ocean Research Institute, University of Tokyo, Tokyo 164, Japan.
}

Gettrust, et al., 1987; Menard, Natland, Jordan, Orcutt, et al., 1987). Results from these experiments in comparison with simultaneous ocean bottom seismometer (OBS) measurements showed improvements in $\mathrm{S} / \mathrm{N}$ ratio for downhole instruments. Also, later phases were also better identified for borehole instruments as they are less affected by boundary layer waves (Stoneley waves).

Decrease in noise level between about 2 and $20 \mathrm{~Hz}$ compared to seafloor observation was about $20 \mathrm{~dB}$ for vertical component and $30 \mathrm{~dB}$ for horizontal component, which further decreased $10 \mathrm{~dB}$ after 9 months of installation in the successful fourth experiment (OSSIV) by HIG (Duennebier, Stephen, Gettrust, et al., 1987). It was $10-15 \mathrm{~dB}$ and $25-30 \mathrm{~dB}$ improvement over OBS observation for vertical and horizontal components, respectively, in the band 0.6$4.5 \mathrm{~Hz}$ in the successful third deployment (MSS) by NORDA (Menard, Natland, Jordan, Orcutt, et al., 1987).

These findings and our wish to install a broadband instrument coupled directly to the basement rock lead to our utilizing an ODP drilled hole. We here describe our OBDS system and its operation during Leg 128 and the data recovery in May 1990. Its performance is described in a separate paper (Kanazawa et al., this volume). Results on detailed crustal structure and anisotropic characteristics revealed from a controlled source seismic experiment are presented in separate papers (Hirata et al., this volume; Shinohara et al., this volume).

\section{SYSTEM OUTLINE}

We have designed our system to be installed through the drill string in ODP holes without modification to the string or any special equipment. While there are developments for independent installation from scientific drilling operations such as by using a submersible or by wireline reentry (e.g., Legrand et al., 1989), which gives the opportunity of utilizing previously drilled holes and greater flexibility in scheduling, this installation required the drilling vessel to clean the hole and to guide down the instrument.

We decided to make the long-term observation by a seafloor recording unit with a power supply, which is cable linked to the borehole sensor package. This means that visits to site are necessary to recover data and to recharge power. It has basically the same layout as the ocean sub-bottom seismometer systems (OSS) built by the University of Hawaii (Duennebier, Stephen, Gettrust, et al., 1987) (Fig. 2). Other possible methods were: (1) cable link to land, (2) cable link to surface buoy, and (3) acoustic link to ship. The first method 
A

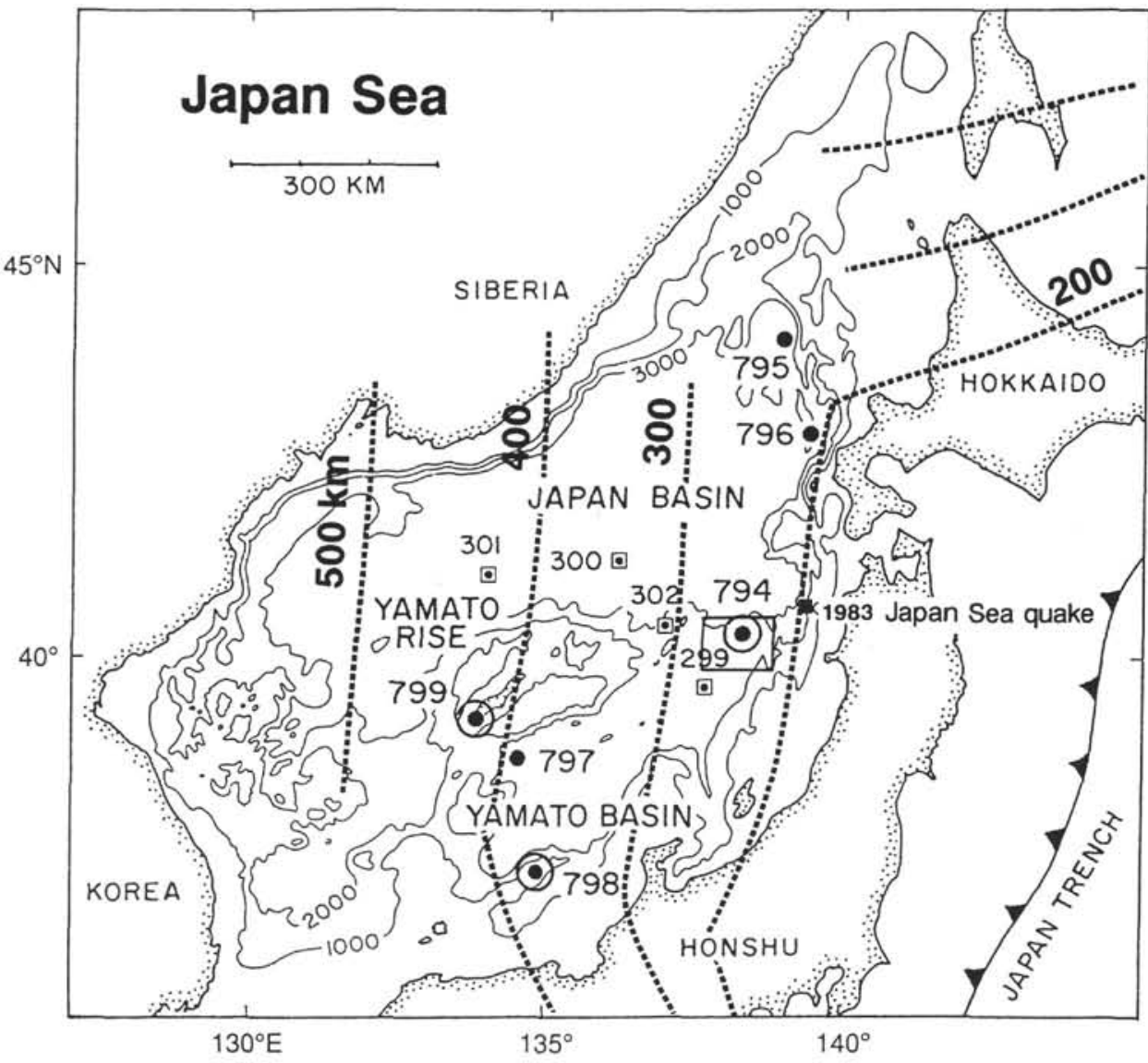

B

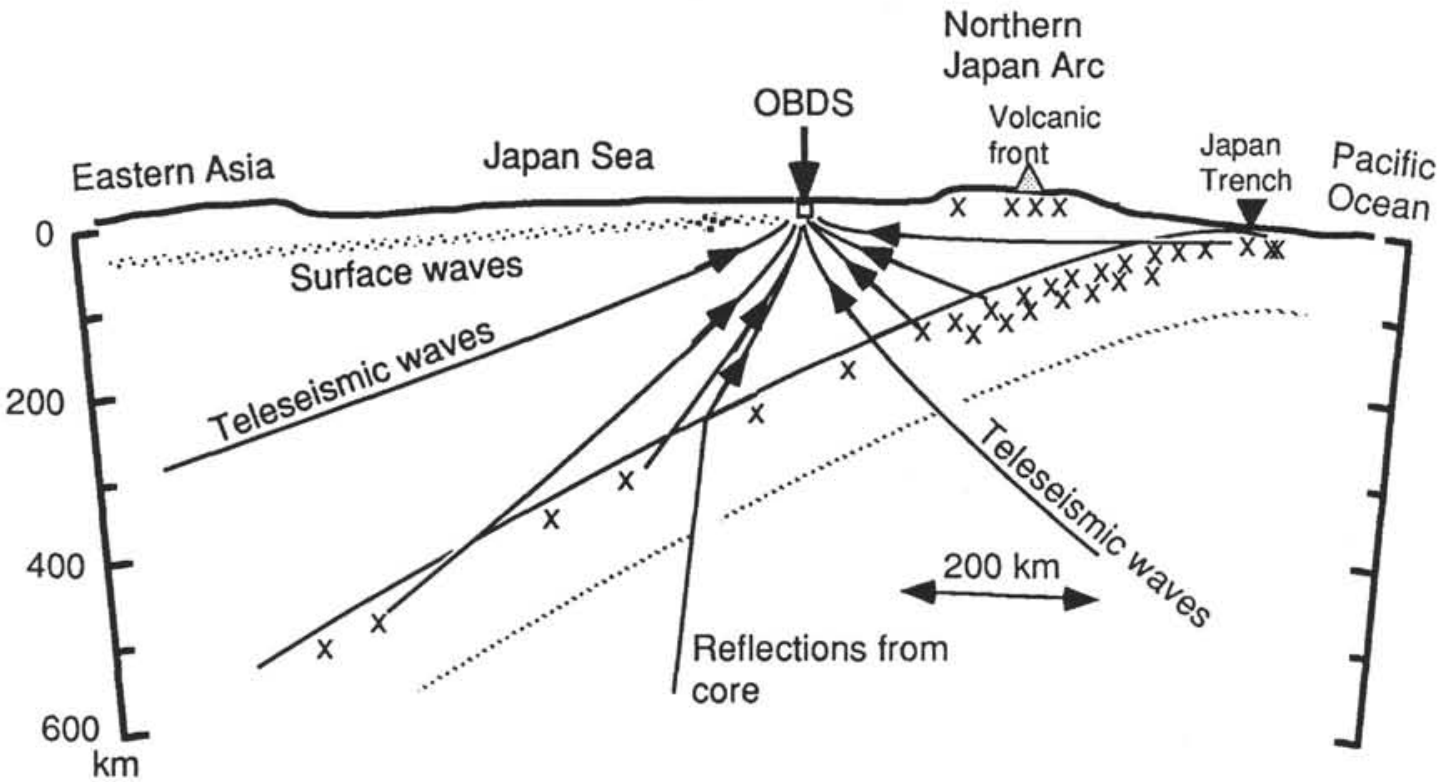

Figure 1. A. Location of downhole seismometer (OBDS) at Site 794 in the Japan Sea. Water depth is $2807 \mathrm{~m}$. Wadati-Benioff zone is indicated by depth contours in broken lines. Location of 1983 Japan Sea earthquake is also shown. Enlargement of area in small rectangle appears in Figure 8. B. Vertical cross section in approximate east-west direction showing various seismic waves from regional earthquakes (crosses) and teleseismic events. Pacific Ocean Plate subducts beneath Japan Island Arc, Japan Sea, and East Asia spanning about $1500 \mathrm{~km}$ horizontally. There have been no seismic stations within Japan Sea. 


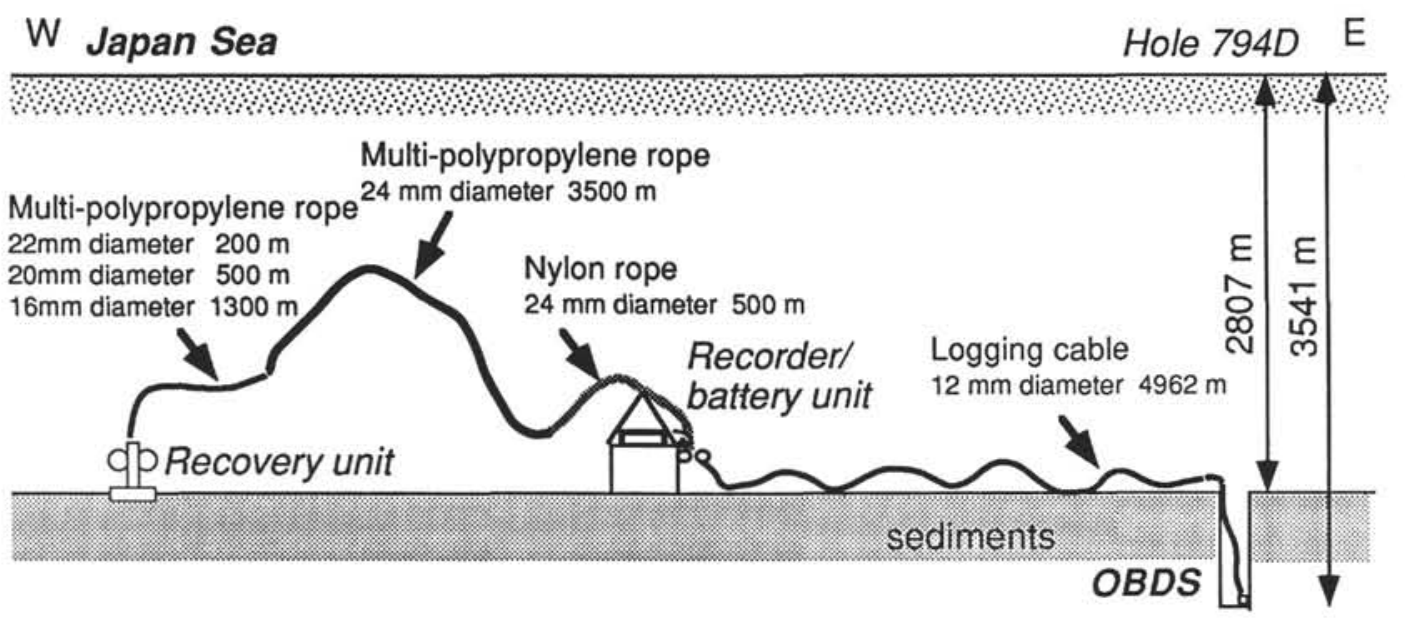

Figure 2. Layout of the OBDS system at off-line observation phase. A recorder/battery unit on the seafloor supplies power to and receives data from OBDS near bottom of Hole 794D via seven-conductor logging cable. Recovery unit releases from its weight by acoustic command from a ship and floats up to surface. Then, a $6000 \mathrm{~m}$ long rope is spooled to retrieve data without stressing the OBDS.

was not feasible costwise since the nearest land was $160 \mathrm{~km}$ away and also because the cable would have to be buried at least part of the way to avoid damage from trawl net fishing. The second method would require a major technical development for a stable operation over a year. The third method is a strong future candidate for data recovery, but cannot supply power.

We proceeded with this design because of our regionally specific objective rather than aiming at routine observation. We started constructing the system in 1987 aiming at using the state-of-theart technology.

The sensor package including the digital data transmission electronics are housed in a stainless steel tube. The inner diameter of the drill pipe, which is nominally 4 in. $(\sim 10 \mathrm{~cm})$ in diameter, and the scheduled hole depth of about $4000 \mathrm{~m}$ delimited the actual sensor diameter to be less than $75 \mathrm{~mm}$. This pressure housing can be clamped within the open hole section which would be about 10 in. $(\sim 25 \mathrm{~cm})$ in diameter in competent rock.

The installation procedure is similar to logging measurements. A standard electromechanical cable for logging was to be used for lowering the instrument and for data/power link (Table 1). The cable would be spliced once in order to pull out the drill pipe.

Table 1. Logging cable specifications.

\begin{tabular}{ll}
\hline Cable weight & $502 \mathrm{~kg} / \mathrm{km}(340 \mathrm{lb} / \mathrm{kft})$ \\
Cable diameter & $12 \mathrm{~mm}(0.464 \mathrm{in}$.) \\
Strength & $7.7 \mathrm{ton}$ \\
Electrical resistance & $34 \mathrm{ohm} / \mathrm{km}(10.4 \mathrm{ohm} / \mathrm{kft})$ (center) \\
& $36 \mathrm{ohm} / \mathrm{km}(10.9 \mathrm{ohm} / \mathrm{kft})($ outer $)$ \\
& $4.3 \mathrm{ohm} / \mathrm{km}(1.3 \mathrm{ohm} / \mathrm{kft})(\mathrm{armor})$ \\
Insulation & $\gg 49 \mathrm{Gohm} / \mathrm{km}(15 \mathrm{Gohm} / \mathrm{kft})$ \\
Capacitance @ 1 kHz & $1.3 \mathrm{pf} / \mathrm{m}(40 \mathrm{pf} / \mathrm{ft})($ armor to outer conductors) \\
& $1.4 \mathrm{pf} / \mathrm{m}(42 \mathrm{pf} / \mathrm{ft})($ armor to center conductors)
\end{tabular}

A digital telemetry technique was adopted to send the data. Realtime observation can be made aboard a vessel provided the other end of the cable is connected to a modem and a personal computer with a large data storage. The logging cable is about $5000 \mathrm{~m}$ length in about $2800 \mathrm{~m}$ water depth, so that accidentally pulling the borehole instrument could be avoided.

Much longer time than real-time observation time is required to record natural earthquakes of interest, which, in our case, are events that provide information on the heterogeneity of the Japan Sea upper mantle. Because of limited data capacity, a continuous recording was not possible. This part of the system is retrievable and, hence, improvements in data storage and power consumption will be sought. Presently, the data recorder and battery pack unit weighs most (about 1.5 tons) in the system. Still, its deployment could be made from a supporting vessel ( $50 \mathrm{~m}$ length class), which also meant maximizing drilling time for the drill ship.

\section{DOWNHOLE PRESSURE HOUSING}

The pressure housing is schematically shown in Figure 3. The overall length is about $300 \mathrm{~cm}$. The outside diameter of $98 \mathrm{~mm}$ ( $3.86 \mathrm{in}$.) was constrained by the drill pipe inner diameter. The sensors and electronics are placed in the top half.

The extension pad and its motor are housed in the bottom half, which can be remote-controlled through logging cable. Single pad ( $32 \mathrm{~cm}$ long $\times 8 \mathrm{~cm}$ wide) retracts to $98 \mathrm{~mm}$ diameter or extends up to $27.2 \mathrm{~cm}$ diameter (10.7 in.) inside the $10 \mathrm{in}$. diameter open hole. The outer surface of the pad has grooves cut in to grip the hole wall.

\section{SENSORS}

No sensors other than a set of three-component seismic sensors were included in order to minimize complication of the system and to consume less power. A feedback type accelerometer was considered to achieve broadband response. On land, many stations had been making broadband high-quality observations using those sensors (e.g., Romanowicz and Dziewonski, 1986). On the other hand, there were no models available for seafloor downhole observations (e.g., Purdy and Dziewonski, 1989).

We selected Guralp's modified CMG-3 (Table 2). Its vertical component consists of a horizontal boom supported by a triangular leaf spring. The natural period of the pendulum is about $0.4 \mathrm{~s}$. The horizontal movement is sensed by an inverted pendulum with similar period as the vertical component. The boom position is sensed by a differential capacitive displacement transducer. The feedback is applied by an electrodynamic transducer.

These masses can be locked upon installation by micromotors. The vertical sensor is designed to operate normally up to $5^{\circ}$ tilt. ODP holes are expected to be less than $3^{\circ}$ from vertical (G. Foss, pers. comm., 1989). The leveling of a horizontal component is achieved by a motor-driven sensor base (PI. 1). 


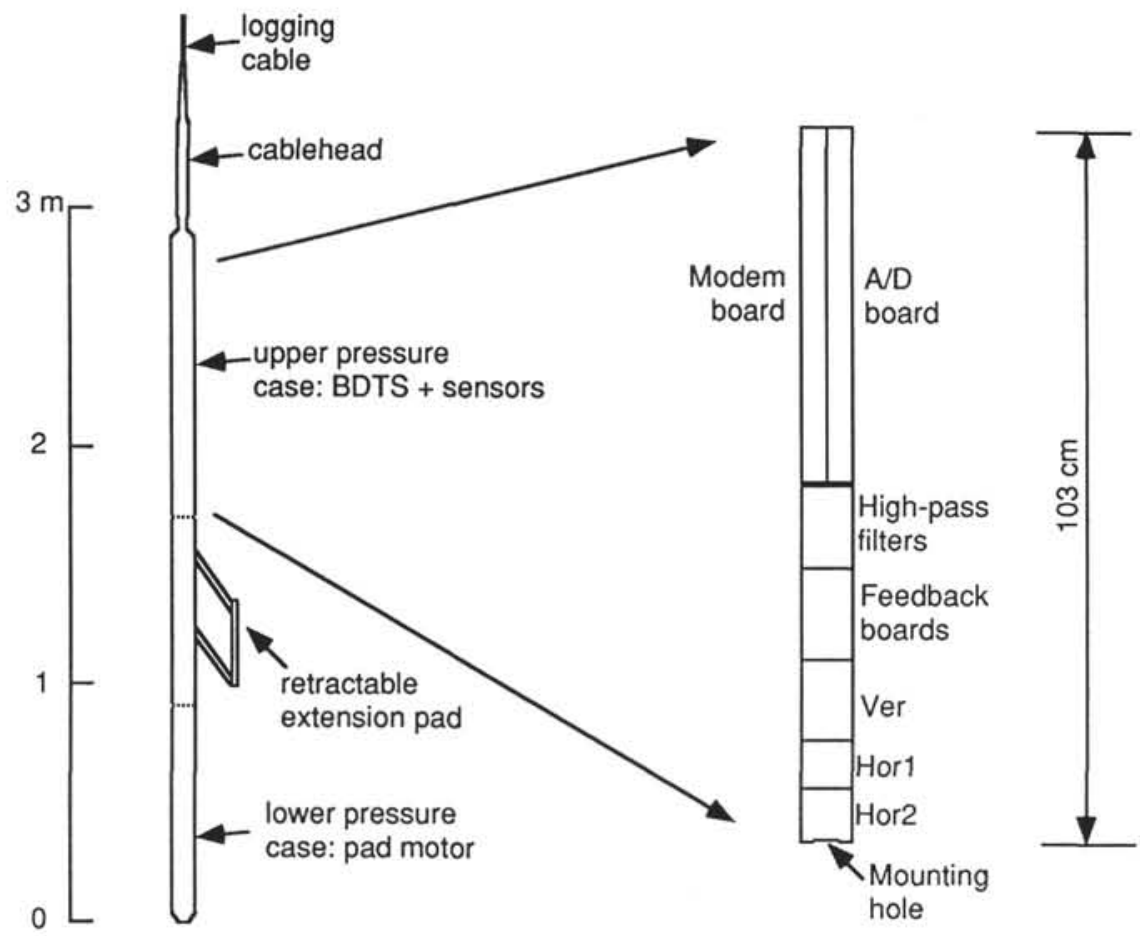

Figure 3. Pressure housing of downhole seismometer (left) and internal sensor package (right). Extension pad is retracted when inside the drill pipe and extends out by pad motor housed near bottom to clamp itself in open hole. A three-axis feedback-type accelerometer constitutes the heart of OBDS. Observed signals are amplified, filtered, digitized, and telemetered uphole.

The three-component sensors are stacked to fit in the pressure housing (Pl. 1). A wide dynamic range is achieved by dividing the signals into two gains. The high-gain channels are amplified by a factor of 6 and low-cut-filtered (Table 2). The feedback sensor package mates directly to the broadband digital telemetry package (BDTS) via a 32-pin connector (Fig. 3).

\section{DATA/POWER LINK}

Figure 4 shows the data and power transmission diagram. Data consist of commands sent downhole and digital seismic signals with replies to commands. There are two electronic boards that constitute the BDTS. One is the A/D converter and the other is the telemetry unit (Table 3). Its test was made by inputting calibration signals of different levels to confirm linear response. As the sensors must

Table 2. Guralp sensor specifications.

\begin{tabular}{|c|c|c|c|}
\hline \multirow[t]{2}{*}{ Type } & \multicolumn{3}{|c|}{$\begin{array}{l}\text { Guralp DT008A slimline CMG-3 } \\
\text { Three-axis feedback accelerometers }\end{array}$} \\
\hline & $160 \mathrm{~g}$ & & \\
\hline Sensitivity & Vertical & Horizontal 1 & Horizontal 2 \\
\hline Low-gain $(\mathrm{DC} 30 \mathrm{~Hz})$ & 2566 & 2700 & $2854 \mathrm{Vm} / \mathrm{s}^{2}$ \\
\hline High-gain $(0.01-30 \mathrm{~Hz})$ & 15396 & 16200 & $17124 \mathrm{Vm} / \mathrm{s}^{2}$ \\
\hline Resolution (LSB) & \multicolumn{3}{|l|}{$0.346 \mathrm{mV}$} \\
\hline Dynamic range & \multicolumn{3}{|c|}{ 16-bit ( $96 \mathrm{~dB})$ each gain; (112 dB total) } \\
\hline Leveling control & \multicolumn{3}{|c|}{$\begin{array}{l}\text { Vertical: mass centering by command-driven motor } \\
\text { Horizontal: mass centering by command-driven } \\
\text { motor and sensor base levelling (accommodates } \\
5^{\circ} \text { of tilt) }\end{array}$} \\
\hline Power & \multicolumn{3}{|c|}{$\begin{array}{l} \pm 12 \mathrm{~V} \pm 15 \mathrm{~mA} \text { (including feedback and filter } \\
\text { electronics when quiet) }\end{array}$} \\
\hline Sensor package & \multicolumn{3}{|c|}{$525 \mathrm{~mm}$ length, $75 \mathrm{~mm}$ diameter } \\
\hline Input/Output & \multicolumn{3}{|c|}{$\begin{array}{l}\text { 32-pin circular connector ( } 12 \text { pins for } 6 \text {-channel } \\
\text { signals; } 11 \text { pins to command lock, center, calibrate } \\
\text { each component; } 3 \text { pins for power) }\end{array}$} \\
\hline
\end{tabular}

withstand forces exerted during installation and because there is no way to check the system other than via the logging cable after installation, sensor controls and checking the state of health (SOH) must be included in the system.

We tested the system with a simulated cable based on logging cable specifications (Table 1). A DC-DC converter requiring two lines for power did not work well when there was considerable impedance before power supply. We increased this to three lines and changed it to regulate with Zener diodes and power regulator IC's. The armor was used to ground the power line. Final test was made aboard JOIDES Resolution through $10 \mathrm{~km}$ of logging cable and a simulated cable. For the case of seafloor observation, the cable length would be

\section{Table 3. BDTS specifications.}

A/D converter Crystal Semiconductor CS501 6: 16-bit, $150 \mathrm{~mW}$, non-linearity $0.001 \%$ maximum

\begin{tabular}{|c|c|c|}
\hline Digital telemetry & Communication rate & Modulation \\
\hline Downhole & $150 \mathrm{bps}$ & FSK (frequency shift key) \\
\hline Uphole & 19,200 bps & DPSK (differential phase) \\
\hline \multirow[t]{9}{*}{ Data packet: 15-byte } & Bytes & Content \\
\hline & $1-2$ & Vertical low gain \\
\hline & $3-4$ & Vertical high gain \\
\hline & $5-6$ & Horizontal-1 low gain \\
\hline & $7-8$ & Horizontal-1 high gain \\
\hline & $9-10$ & Horizontal-2 low gain \\
\hline & $11-12$ & Horizontal-2 high gain \\
\hline & 13 & State-of-health (SOH) \\
\hline & $14-15$ & status \\
\hline \multirow[t]{7}{*}{ Available commands } & \multicolumn{2}{|l|}{ Get values from SOH 8-bit A/D's } \\
\hline & \multirow{2}{*}{\multicolumn{2}{|c|}{ Get internal variables, e.g., lock status }} \\
\hline & & \\
\hline & \multicolumn{2}{|c|}{ Automatic centering of mass of each component } \\
\hline & \multicolumn{2}{|c|}{ Mass locking/unlocking of each component } \\
\hline & \multicolumn{2}{|c|}{ Base locking/unlocking of each horizontal component } \\
\hline & \multicolumn{2}{|c|}{ Star/stop automatic centering mode (automatic centering every $11 \mathrm{~min}$ ) } \\
\hline
\end{tabular}




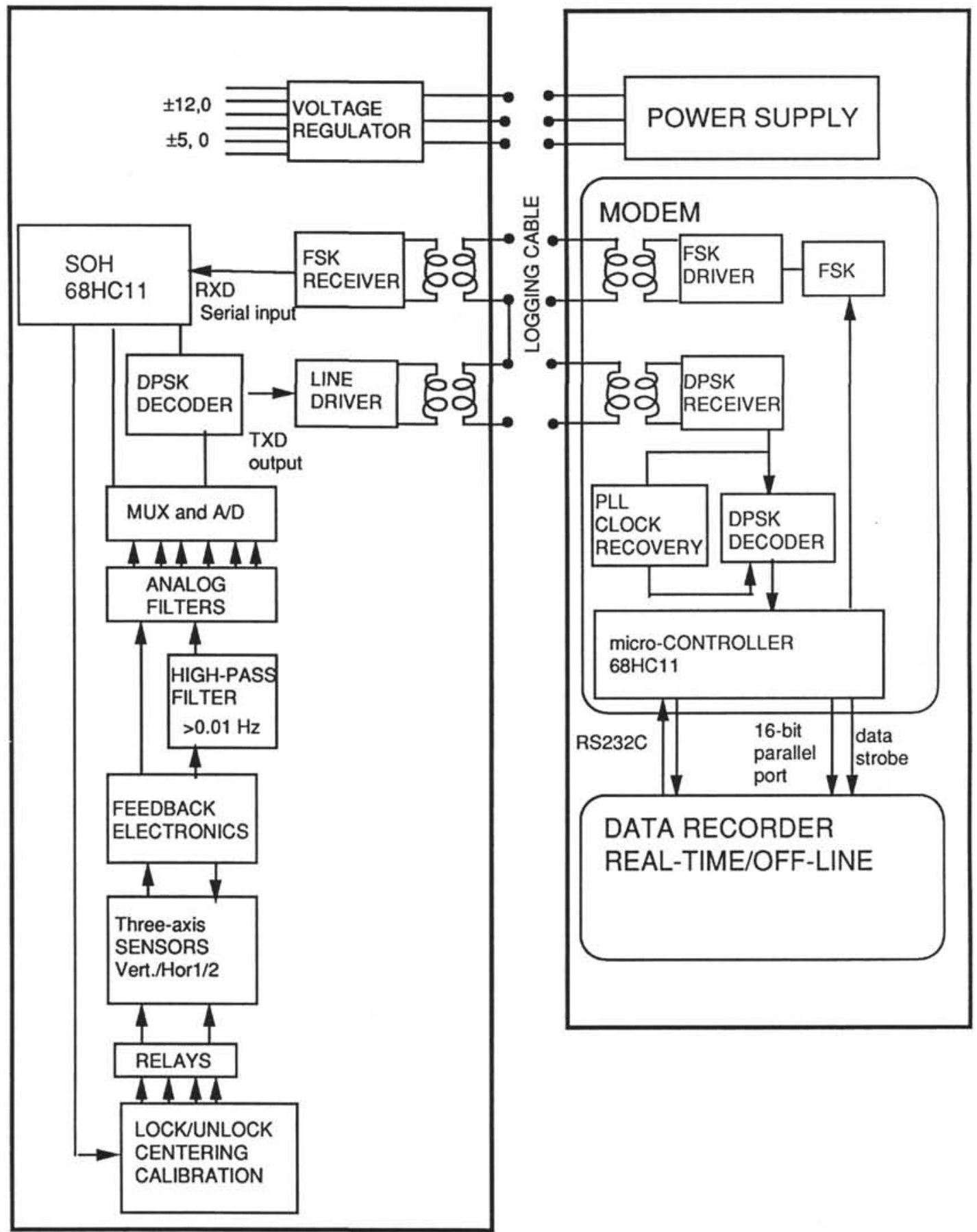

Figure 4. Data and power link between downhole unit and uphole. Power is sent via \#2 (+48 V), \#5 (-48 V), and \#1 armor (GND) of seven-conductor double armored logging cable. Data are transmitted uphole ( $\# 4$; $\# 6$ common) and commands sent downhole (\#3; \#6 common). Pad motor uses \#7 and GND (not shown).

about $5 \mathrm{~km}$. Power supply tests indicated that in order to receive data, $+48 \mathrm{~V}$ and $-36 \mathrm{~V}$ were the minimum required.

\section{SEAFLOOR UNIT}

\section{Seafloor Data Recorder}

We have made a re-use of the cylinder pressure vessel originally developed by Nagumo et al. (1970). It was tested to pressure equiva- lent to $4000 \mathrm{~m}$ water depth. The only modification was to attach a connector to couple the logging cablehead. This vessel was attached on top of the battery unit with care to avoid electrical corrosion by allowing no direct metal contacts.

Inside this housing are a modem, data logging controller, and recorder (Fig. 5, Table 4). The recorder is a self-contained package communicated through an RS-232 interface. A cartridge tape runs in start-stop mode to store up to 60 Mbytes, which can operate up to 


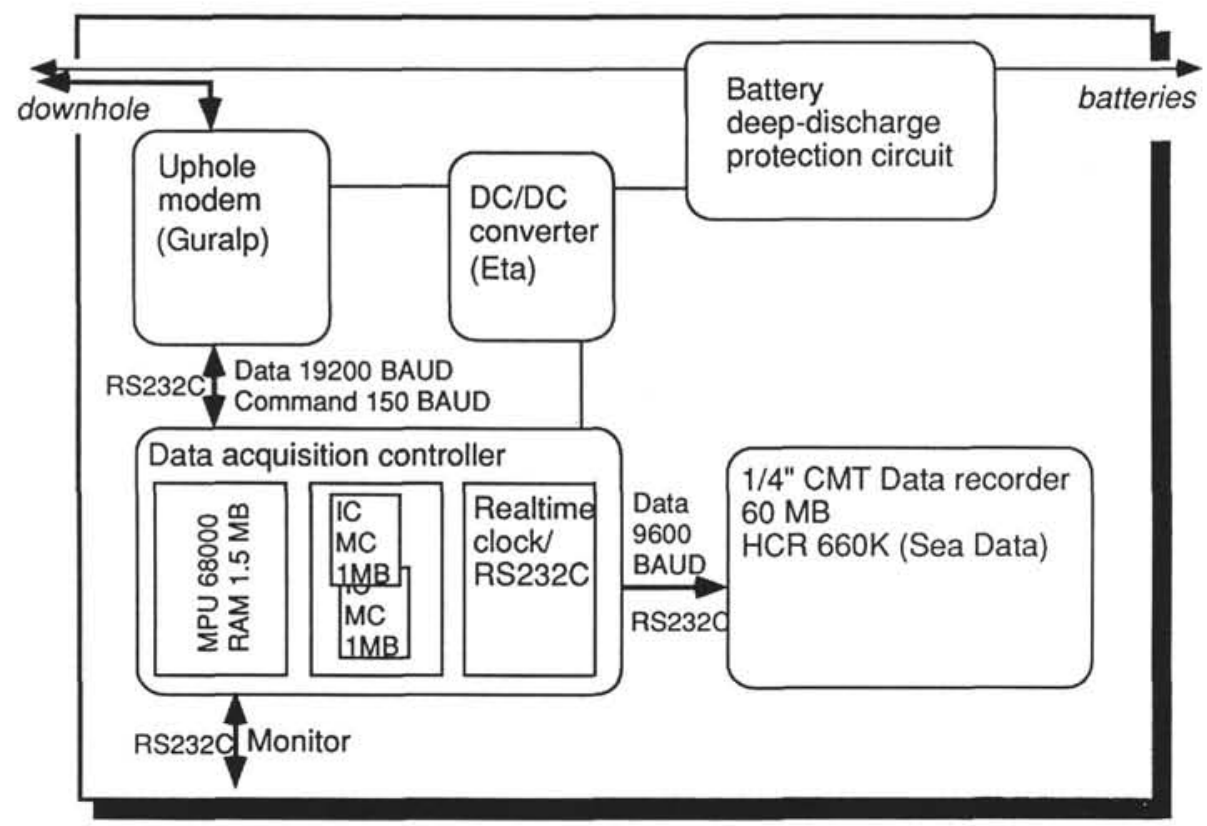

Figure 5. Block diagram of seafloor data recorder. Data are stored digitally in a $60 \mathrm{Mbyte}$ cartridge disk. Two IC memory cards are for data buffering.

about a year. The data acquisition controller does data selection in two modes: (1) event detection mode and (2) time window mode (Fig. 6; Table 4). It buffers data onto two 1 Mbyte IC memory cards before outputting to the recorder.

The event detection mode uses an algorithm of triggering by setting a STA/LTA (short term average/long term average) threshold. Aiming at moderate to large earthquakes, two sampling rates were selected; $20 \mathrm{~Hz}$ and $1 \mathrm{~Hz}$. The former is called SP (short period), and recording is made for $40 \mathrm{~min}$. The latter is called LP (long period) and will record for $2 \mathrm{hr}$ per event. Both are triggered independently where STA means taking an average of 10 samples and LTA, of 1000 samples; that is, the amplitude changes at two different frequency bands are monitored. Two threshold levels may be selected, and in the case where the first threshold level fails to trigger any event, the second level is adopted. In this experiment, we chose four and two in that order. No detection takes place while data are being recorded.

A time window recording was incorporated to study the background noise level. Three different frequency bands and time dura-

Table 4. Data recording scheme.

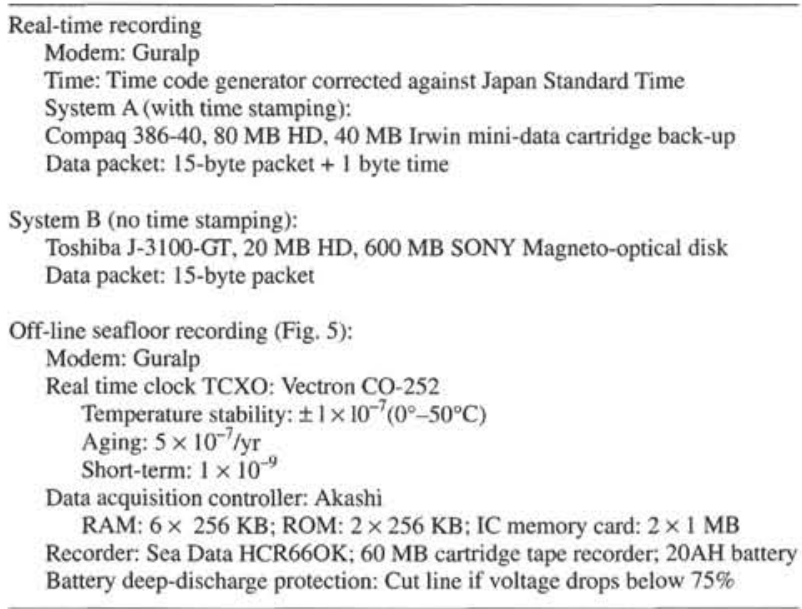

tions were set up as shown in Figure 6. This mode has lower priority than the event detection mode, so that interruption may occur.

\section{Power Supply}

Power requirements for this experiment are shown in Table 5. It can be seen that the logging cable itself is a major power dissipator, and it is far more than an all-in-one OBS with a passive sensor system. We chose to use lead-acid batteries with nonliquid electrolytes in pressure-compensated housings, similar to the type used by deep submersibles. The lead-acid type was selected over $\mathrm{Ag}-\mathrm{Zn}$ or Ni-Cd type, the energy density of which are superior but much more costly. Since the electrolyte is solid, the batteries may be placed upside down upon deployment.

Table 5. Power requirements.

\begin{tabular}{ll}
\hline Downhole via logging cable: & $-48 \mathrm{~V},-148.5 \mathrm{~mA}, 7.1 \mathrm{~W}$ \\
& $+48 \mathrm{~V}, 200 \mathrm{~mA}, 9.6 \mathrm{~W}$ \\
BDTS demodulator & $-12 \mathrm{~V}, 26 \mathrm{~mA}, 2.3 \mathrm{~W}(48 \mathrm{~V}$ equiv $=6.5 \mathrm{~mA})$ \\
& $+12 \mathrm{~V}, 96 \mathrm{~mA}, 0.6 \mathrm{~W}(48 \mathrm{~V}$ equiv $=24 \mathrm{~mA})$ \\
Akashi controller & $1.92 \mathrm{~W}(+24 \mathrm{~V}, 80 \mathrm{~mA})(48 \mathrm{~V}$ equiv $=40 \mathrm{~mA})$ \\
\hline
\end{tabular}

Twenty batteries are put together inside an aluminum frame, making this part the heaviest (about 1 ton in air) component of the seafloor unit (Table 6). This can be serviced by a vessel larger than about $50 \mathrm{~m}$ length without heave compensation.

\section{Recovery Unit}

Based on experiences from years of using tethered OBS, nylon and polypropylene rope amounting to $6000 \mathrm{~m}$ length were used to connect the recorder package and acoustic release system (Fig. 2 ). Upon data recovery, the release system is first recovered and then the rope is wound onto a winch to retrieve the data package. We estimated maximum tension to be less than about 3 tons. A nylon rope was used near the recorder. Small-diameter $(16 \mathrm{~mm})$ rope is used near the float for less friction. 


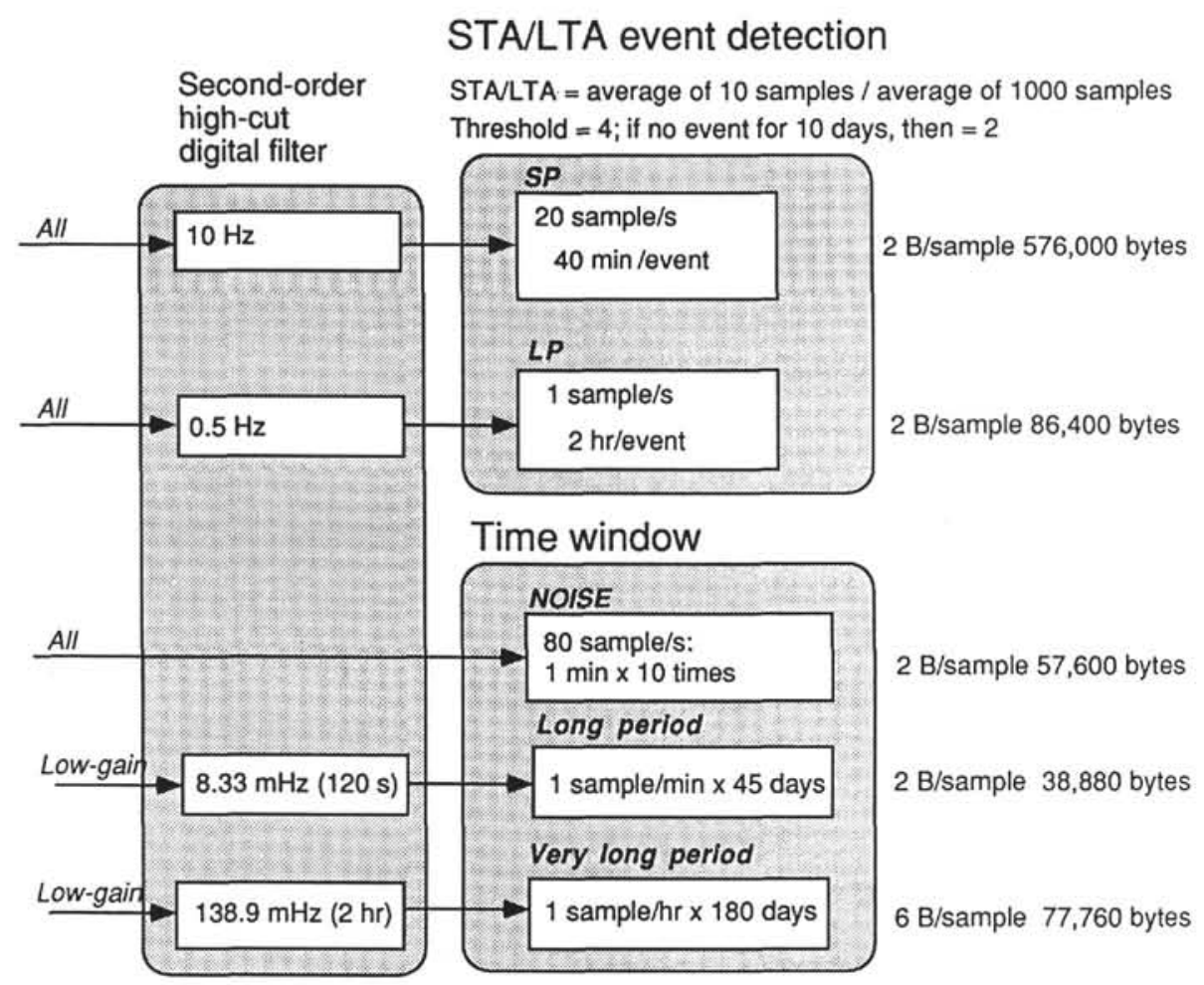

DATA FORMAT

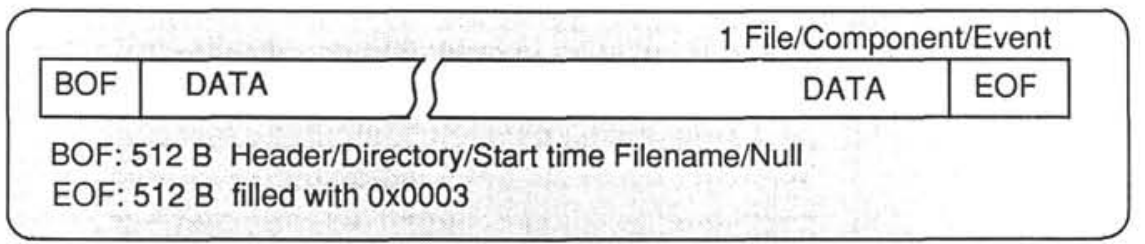

Figure 6. Data selection scheme. Event detection mode and time window mode are available. An event trigger occurs if short term average (STA) and long term average (LTA) ratio exceeds a preset value, in which case, short period (SP) and long period (LP) recordings are made. Time window mode is meant for noise level recording. All samplings are made after appropriate anti-alias filtering.

The acoustic recovery system consists of two $17 \mathrm{in.} \mathrm{glass} \mathrm{spheres}$ for buoyancy and an acoustic releaser placed in the middle with a lifetime of 1 year (extendable) suspending the weight (Pl. 2). The release mechanism is an exploding bolt operated by acoustic command. If this fails to operate, the polypropylene part of the rope system would be picked up.

\section{INSTALLATION}

The original plan was to drill and case Hole 794C on Leg 127, and reuse the hole for our seismic experiment. This would give about 2 months of time to allow the hole to stabilize itself as much as possible before installation. Unfortunately, Hole 794C became unusable when a BHA was left inside the hole during Leg 127. Our attempt to fish this BHA out on Leg 128 failed, and hence, it was quickly decided to drill Hole 794D for the experiment. Two other supporting ships for the geophysical experiments were on tight schedules, and thus little change in timing of the experiment was possible despite these last minute changes.

Table 7 shows the summary of Hole 794D. The casing of the hole through sediment section was important because of swelling clay instantly obstructing the hole for reentry. Logging information was vital to determine that the final position of the borehole instrument was within competent rock section. Figure 7 shows the logging record and the final position of the instrument.

Table 8 shows the sequence of installation operation. It was necessary to lower the drill pipe to near-bottom so that our instrument, much lighter than logging tools, would not be obstructed. The logging cable was

Table 6. Battery specifications and wiring.

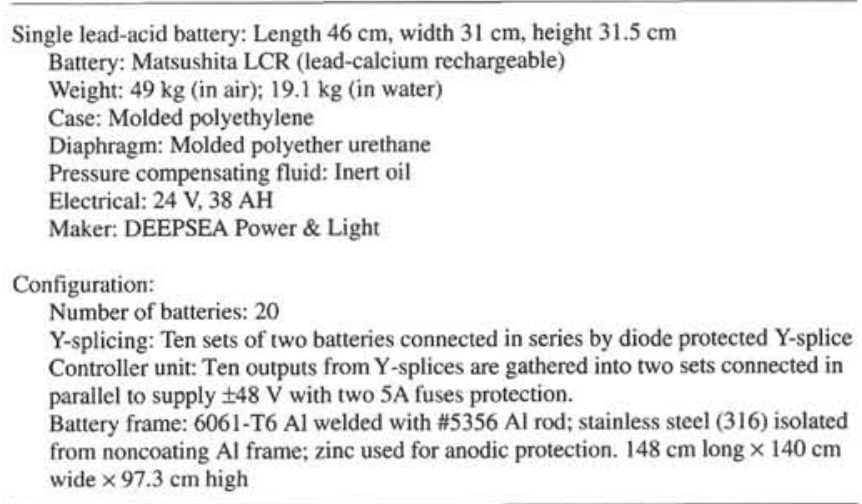


Table 7. Hole 794D.

Position: $40^{\circ} 11.366^{\prime} \mathrm{N}, 138^{\circ} 13.944^{\prime} \mathrm{E}$
Water depth: $2807 \mathrm{~m}$
Penetration: $733.5 \mathrm{~m}$
Sediments: $542.2 \mathrm{~m}$
Hard rock:
Depth (mbsf): 573.0
Nature: Olivine dolerite
Measured velocity: $5.4 \mathrm{~km} / \mathrm{s}$
Drilling dates:
4-13 September: drilled to $666 \mathrm{mbsf}$ and cased through $560 \mathrm{mbsf}$
22-29 September: deepened to 733.5 mbsf and logged
Instrument depth: 714.5 mbsf

reheaded and connected to the downhole seismometer. A final test was made to check the clamping device. Then, the instrument was lowered to and first clamped at $718 \mathrm{mbsf}$. Incoming data were saturated by noise, so we judged from the command performance of the leveling motors for horizontal components, which did not seem to indicate normal function. We decided to reclamp the instrument above the initial position at 714.5 mbsf. This time, the leveling functioned, and the mass on each sensor was swinging between positive and negative maxima.

The next step was pipe stripping. The cable was cut at the rig floor and the pipe stripping proceeded as illustrated by Byrne et al. (1980). We did not retract the pad during this procedure. Two stands of drill-pipe were left to protect the logging cable suspended through the moon pool as the ship would move away from the hole. "Torpedo" splicing was made applying "ScotchKote" at seals for longer duration, and the real-time recording began. One horizontal component was found to be malfunctioning for unknown reason.

The JOIDES Resolution was offset by $1536 \mathrm{~m}$ in $180^{\circ}$ direction while paying out $1353 \mathrm{~m}$ of logging cable to prepare for real-time observation. The offset direction was determined from the OBS array geometry and sea currents (Fig. 8).

\section{REAL-TIME EXPERIMENT}

The real-time experiment lasted for about $60 \mathrm{hr}$ starting from the time of cable splicing until the cutting of the cable to pass to the supporting vessel, Kaiko-maru S. Digital recordings were continuously made during this period onto two personal computer systems (Table 4). The automatic mass centering mechanism was activated during this phase, which meant that the masses would be automatically centered every $11 \mathrm{~min}$.

Two recording systems ran in parallel dedicated to data retrieval for safety. Both should record exactly the same digital signals. One system would put a time stamp when storing data onto a hard disk while the other magneto-optical disk storage system could not. Since the data transmission uphole must maintain 19,200 bps in order to send six channels of $80 \mathrm{~Hz}$ sampling 16-bit data, special coding was necessary to capture and store the data at this rate.

We conducted a controlled source seismic survey during this time to obtain the local crustal structure and to find the azimuths of horizontal sensors. Tansei-maru of Ocean Research Institute, University of Tokyo, shot air guns as a signal source and also deployed nine OBS's for a high-resolution study (Shinohara et al., this volume; Hirata et al., this volume). Two vessels independently corrected time against Japan Standard Time (JJY radio signal).

\section{DEPLOYMENT OF SEAFLOOR UNIT}

After passing the cable to Kaiko-maru 5, a final electrical connection test was made. The clock was started and the data controller power was set. Figure 9 shows a schematic view at the deployment of the seafloor unit. Great care was taken so that no excess tension was applied to the cablehead. The package was lifted over the aft end of the ship by the
Table 8. Downhole seismometer installation.

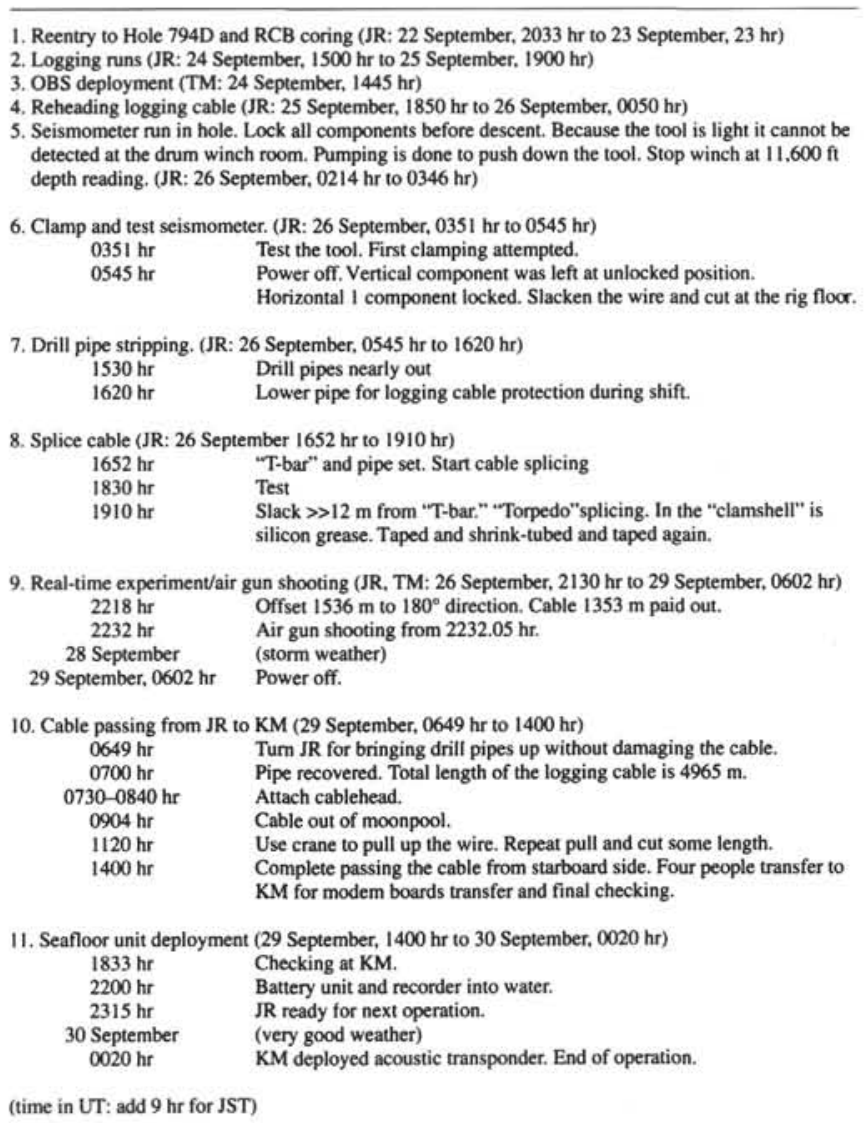

JOIDES Resolution (JR): Downhole seismometer installation Tansei-maru (TM): Air-gun shooting and OBS array observation Kaiko-maru (KM): Seafloor unit deployment

recovery rope which ran through a sheave on an A-frame. After lowering the package into the sea, the ship drifted while the crew was paying out the rope system. Several hundred kilograms of tension was maintained during this operation to pull the cable and rope.

\section{RECOVERY}

In May 1990, we revisited the site to recover the seafloor system. A chartered ship of about $50 \mathrm{~m}$ length was equipped with a winch with a load cell to monitor load during recovery. First, as we approached the site, three transponders were deployed to determine the ship position, in addition to GPS aid. The weight was successfully released by acoustic command and the float was recovered. It took $5 \mathrm{hr}$ from that time to retrieve the seafloor recorder. The rope tension increased eventually to 2.5 ton.

No apparent damage was found to the recorder or to the battery unit. There was no electrical corrosion on the surfaces of these units. Inside, the cartridge tape was advanced only a little. There was no triggering from the event despite the fact that there should have been. The reason for this is probably because of DC offset in the data and telemetry problem. Available data then are from IC memory cards only.

We made an overnight effort to revive the system by trying a real-time observation. It was found that the error rate in data telemetry had increased considerably, the reason of which is under investigation. We redeployed only the recovery unit, which took $3 \mathrm{hr}$. The data recorder and the battery unit were brought back for closer inspection and for modification and recharging. 


\section{Hole $794 D$}

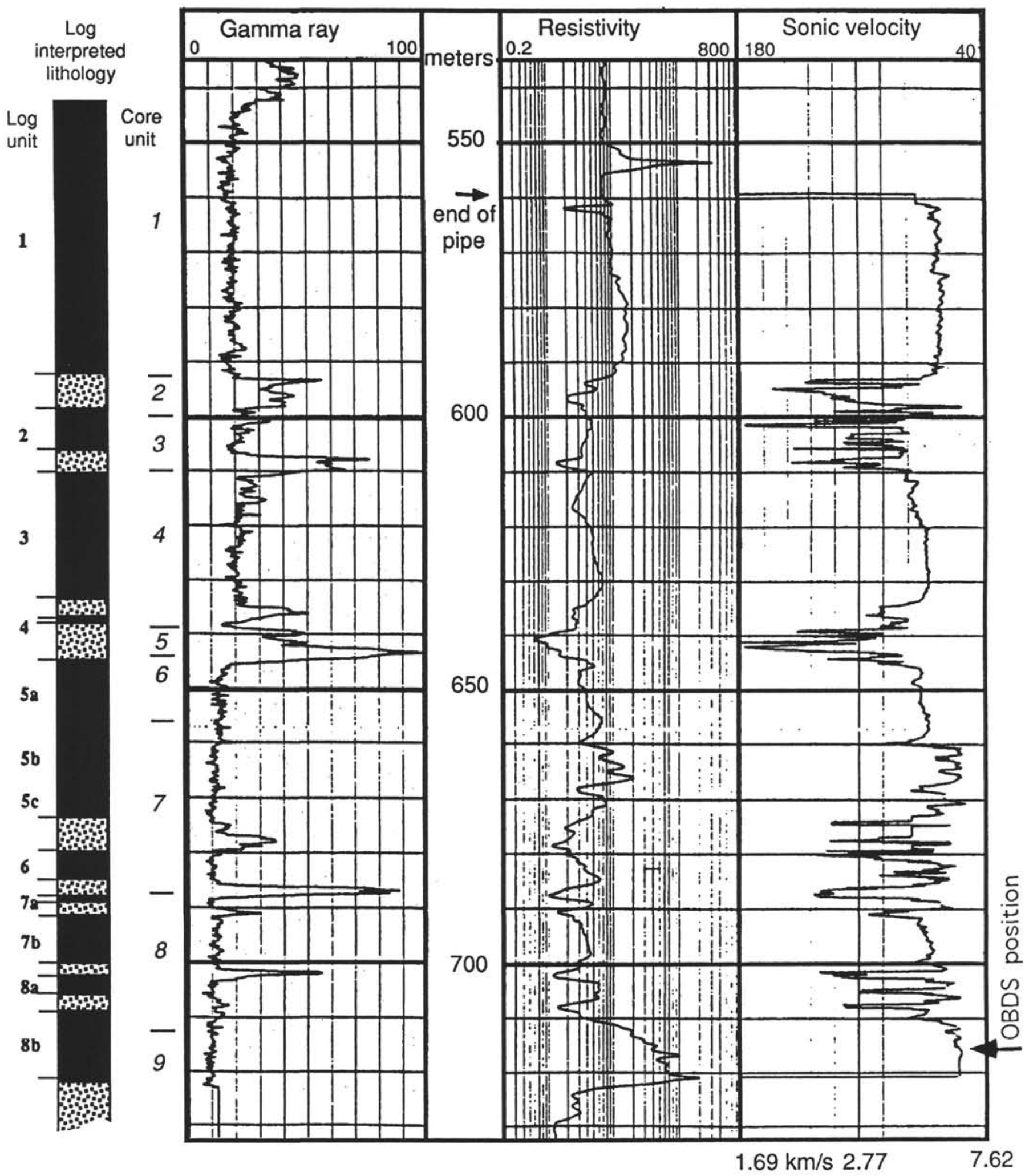

Figure 7. Seismic stratigraphy combination log record. Column 1 is interpreted lithology (see Ingle, Suyehiro, von Breymann, et al., 1990). Logging records are, from left, total gamma rays ( $0-100$ API units), resistivity (phasor induction medium, $0.2-800 \mathrm{ohm}-\mathrm{m}$ ), and sonic traveltime $(180-40 \mu \mathrm{s})(\mathrm{velocity}$ indicated below). An arrow at lower right shows the position of seismic sensor within low gamma ray, high resistivity, high velocity medium at $714.5 \mathrm{mbsf}$ or $3522 \mathrm{~m}$ from surface. 


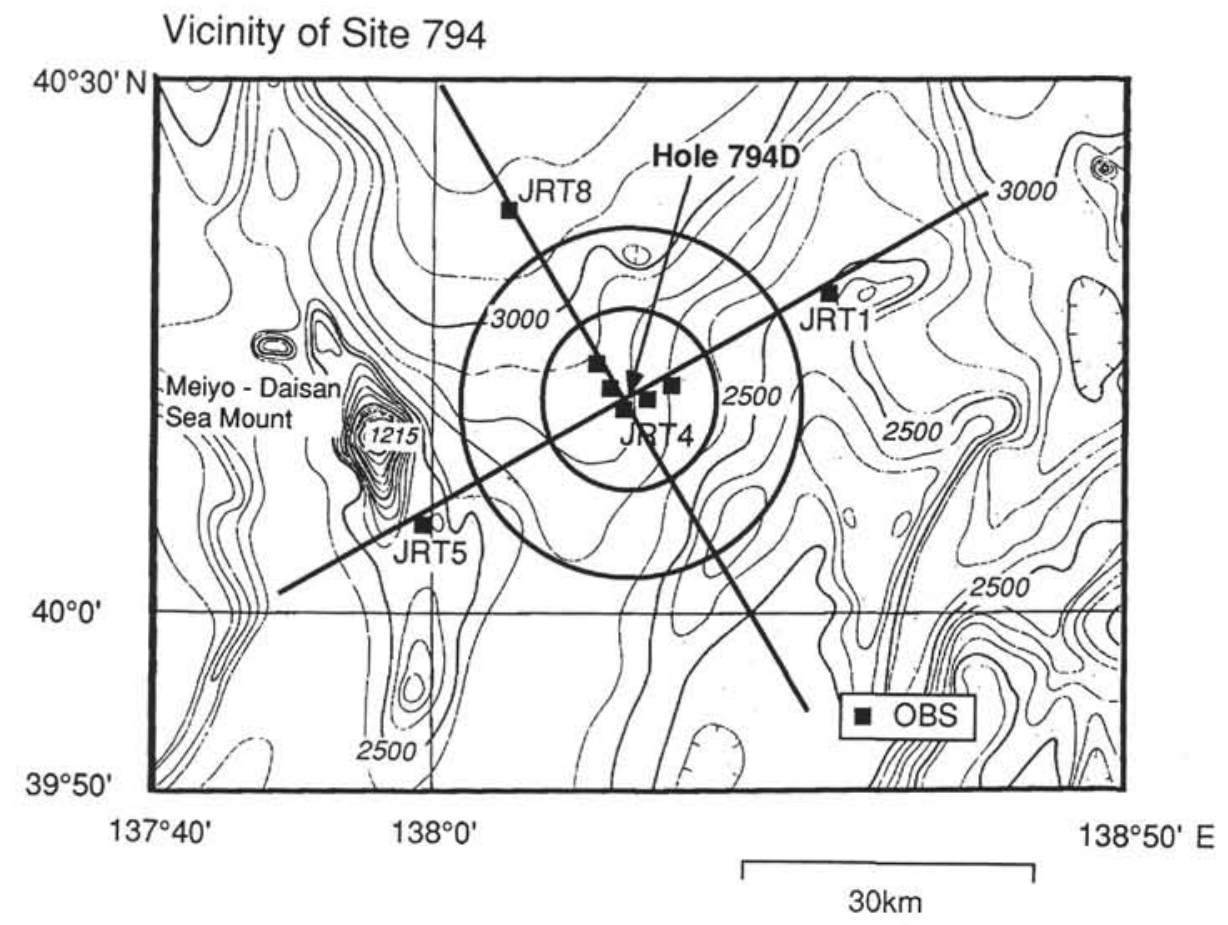

Figure 8. Detailed map of Site 794 vicinity. OBS-array location and air-gun profiles in solid lines are shown. Seafloor recorder unit and recovery unit lie westward of Hole 794D.

\section{SUMMARY}

In summary, we have constructed a digital downhole seismometer system with broadband and wide dynamic range response (OBDS) to be installed in an ODP hole. Its installation was attempted in the fall of 1989 on ODPLeg 128 in the Japan Sea and was successful. The OBDS was emplaced at a depth of $714.5 \mathrm{mbsf}$ within basaltic rock section at Site 794. Sixty hours of real-time digital recording was made from JOIDES Resolution through the logging cable, including controlled seismic source signals, for the first time in broadband. Two components of the feedback-type accelerometers operated normally.

A support vessel brought the seafloor recorder unit to be connected to the cable and deployed the unit to capture deep or teleseismic events

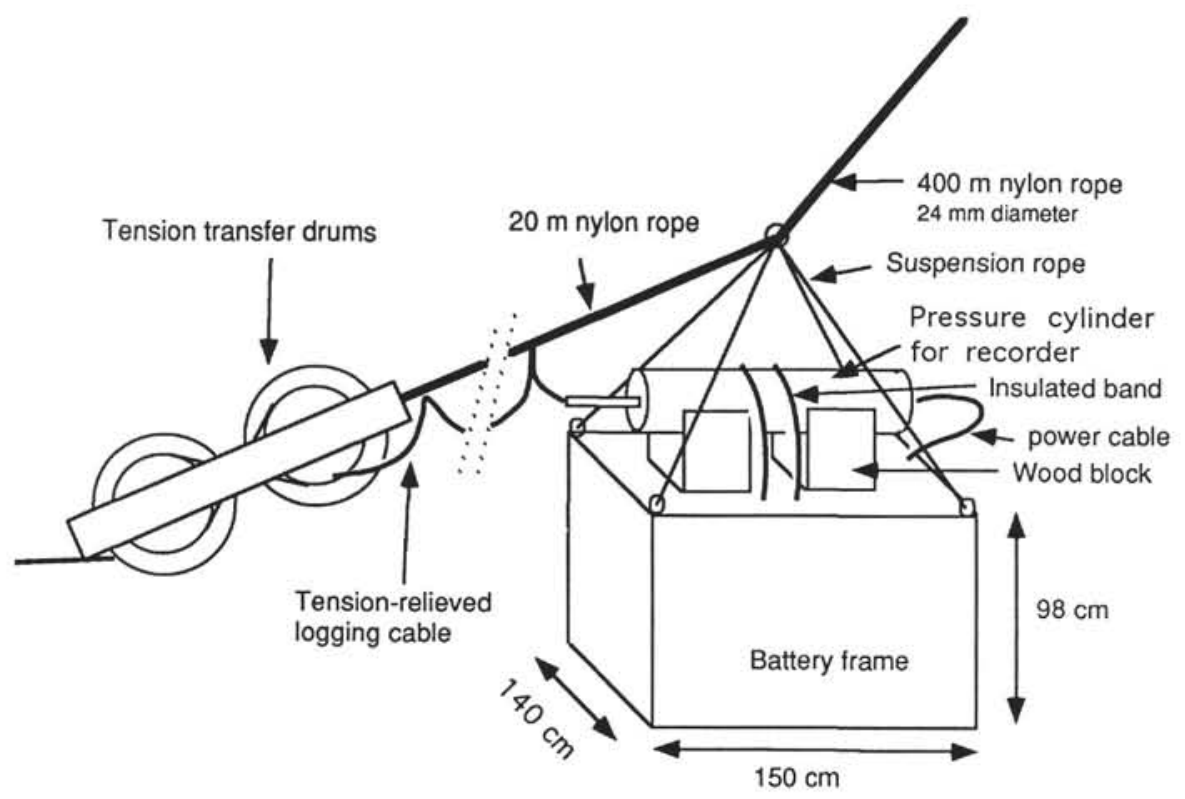

Figure 9. Deployment of seafloor unit. Cylinder is the pressure housing of data recorder attached without direct metal contacts to aluminum battery frame. Tension of the logging cable is transferred to rope, so that little tension applies to cablehead. The unit was put into water by an A-frame from aft of Kaiko-maru 5. 
together with ambient noise. Pressure-compensated lead-acid batteries were configured in an aluminum frame as the main power supply, which also holds the cylinder vessel with the data recorder on its top. A rope system of $6000 \mathrm{~m}$ length is attached with the recovery unit at the end (Fig. 2).

The seafloor unit was recovered after about 8 months underwater without any electrical or mechanical damage. Unfortunately, the event detection had not functioned, although there were a number of large events worldwide including the Loma Prieta earthquake.

Modifications can be made only for the seafloor units. Plan is underway to improve the system as there is no definite evidence that the downhole instrument has irreversibly gone wrong. The present system allows only about 1.5 months of operation. We are considering alternate power sources, such as fuel cells or isotope cells, for the future to prolong life to years. The data capacity should also be increased. We are currently developing a digital audio tape-based seafloor data recorder, which can store 1 Gbyte of data in a much smaller size and with less power con sumption than our present system.

\section{ACKNOWLEDGMENTS}

This kind of experiment requires the coordination of many people from different fields or professions. Indeed in our case, it was also truly international, and it is difficult to name all the people involved. We owe very much to ODP engineers and technicians and the Schlumberger engineer aboard JOIDES Resolution on Leg 128 as well as those who stayed in College Station, who were helpful from the developing stage of this experiment. Among them we specially thank Jim Briggs, Lee Geiser, Gus Gustafson, Hiroshi Matsuoka, and Gene Pollard. We thank all the onboard scientists, including Toshio Tozawa and Hiroki Nambu aboard Kaiko-maru 5 and Azusa Nishizawa aboard Wakashio-maru. Co-chief Jim Ingle persistently encouraged us without putting on us too much pressure. Captains and crews of these three vessels are greatly appreciated for their skills.

\section{REFERENCES}

Aubouin, J., von Huene, R., et al., 1982. Init. Repts. DSDP, 67: Washington (U.S. Govt. Printing Office).

Biju-Duval, B., Moore, J. C., et al., 1984. Init. Repts. DSDP, 78A: Washington (U.S. Govt. Printing Office).
Byrne, D. A., Harris, D., Duennebier, F. K., and Cessaro, R., 1987. The ocean sub-bottom seismometer system installed in Deep Sea Drilling Project Hole 581 C, Leg 88: a technical review. In Duennebier, F. K., Stephen, R. A., Gettrust, J. F., et al., Init. Repts. DSDP, 88: Washington (U.S. Govt. Printing Office), 65-88.

COSOD II, 1987. Rep. 2nd Conf. Sci. Ocean Drilling. Strasbourg, France, (European Science Foundation).

Duennebier, F. K., Stephen, R. A., Gettrust, J. F., et al., 1987. Init. Repts. DSDP, 88: Washington (U.S. Govt. Printing Office).

Hyndman, R. D., Salisbury, M. H., et al., 1984. Init. Repts. DSDP, 78B: Washington (U.S. Govt. Printing Office).

Ingle, J. C., Jr., Suyehiro, K., von Breymann, M., et al., 1990. Proc. ODP, Init. Repts., 128: College Station, TX (Ocean Drilling Program).

Legrand, J., Echardour, A., Floch, H., Floury, L., Gieskes, J., Harmegnies, F., Loaec, G., Pozzi, J.-P., Raer, Y., and Stephen, R., 1989. Campagne FARE, wireline reentry of DSDP Hole 396B using the NADIA system. Eos, 70:729-730.

Lewis, B.T.R., Robinson, P. T., et al., 1983. Init. Repts. DSDP, 65: Washington (U. S. Govt. Printing Office).

Menard, H. W., Natland, J. H., Jordan, T. H., Orcutt, J. A., et al., 1987. Init. Repts. DSDP, 91: Washington (U.S. Govt. Printing Office).

Nagumo, S., Kobayashi, H., Koresawa, S., and Takeyama, T., 1970. Pressure vessels for ocean-bottom seismograph. Tokyo Daigaku Jishin Kenkyusho Iho, 48:955-966. (in Japanese)

Purdy, G. M., and Dziewonski, A. M., 1989. Proc. Workshop on Broad-band Downhole Seismometers in the Deep Ocean. Woods Hole, MA, Apr. 26-28, 1988 (Joint Oceanogr. Inst. and U.S. Sci. Advisory Comm.)

Romanowicz, B., and Dziewonski, A. M., 1986. Towards a federation of broadband seismic networks. Eos, 67:541-542.

Stephen, R. A., Johnson, S., and Lewis, B., 1983. The oblique seismic experiment on Deep Sea Drilling Project Leg 65. In Lewis, B.T.R., Robinson, P. T., et al., Init. Repts. DSDP, 65: Washington (U.S. Govt. Printing Office), 319-327.

Stephen, R. A., Louden, K. E., and Matthews, D. H., 1980. The oblique seismic experiment on DSDP Leg 52. Geophys. J. R. Astron. Soc., 60:289-300.

Sutton, G. H., McDonald, W. G., Prentiss, D. D., and Thanos, S. N., 1965. Ocean-bottom seismic observatories. Proc. IEEE, 53:1909-1921.

Date of initial receipt: 26 March 1991

Date of acceptance: 28 February 1992

Ms 127/128B-226 


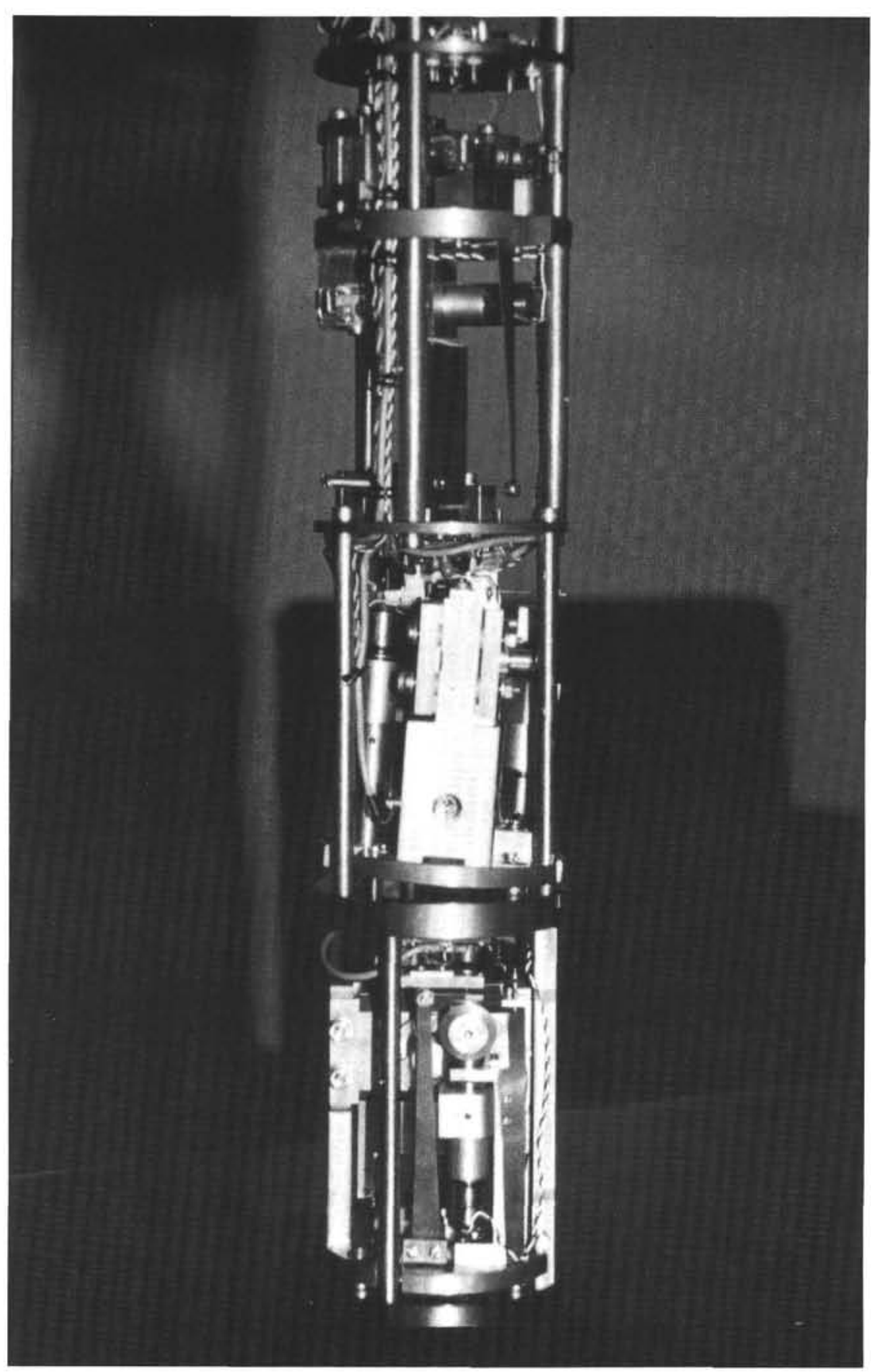

Plate 1. Guralp three-axis feedback-type accelerometer sensor stack-up. A vertical sensor sits on top of two mutually orthogonal horizontal sensors. Bases of horizontal sensors tilt in the direction of inverted pendulum movement to become horizontal accommodating up to $5^{\circ}$ deviation from vertical. 


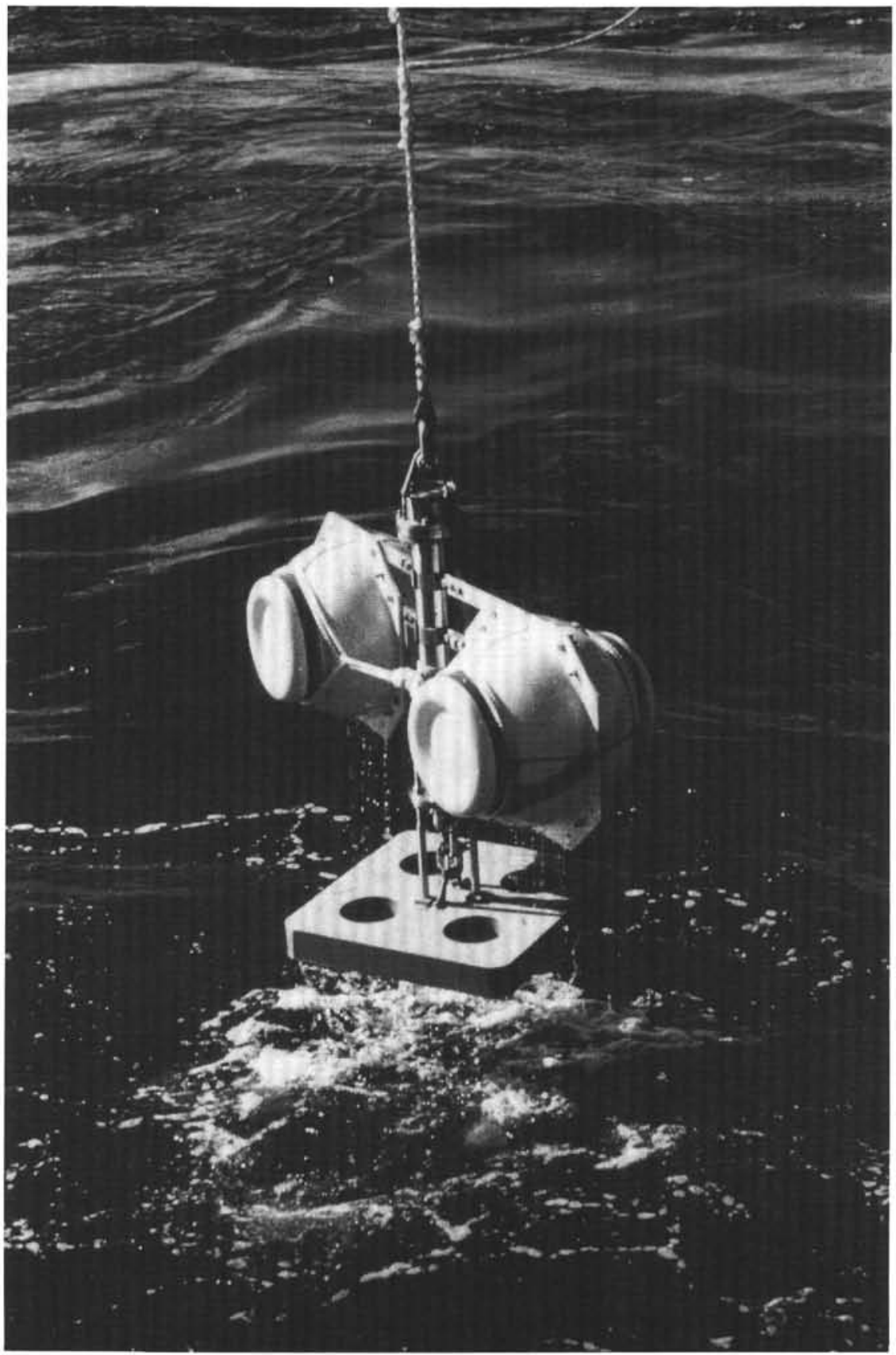

Plate 2. Acoustic recovery system. Two glass spheres cradle an acoustic releaser suspending a $150 \mathrm{~kg}$ iron weight. 